РОЗВИВАЮЧИЙ ВПЛИВ ХОРЕОГРАФІЧНОГО МИСТЕЦТВА НА ОСОБИСТІСТЬ ШКОЛЯРА

\title{
DEVELOPING INFLUENCE OF CHOREOGRAPHIC ART ON PUPIL'S PERSONALITY
}

Mета статmі полягає у визначенні та науковому обгрунтуванні організаційно-педагогічних умов проведення хореографрічних занять у закладі загальної середньої освіти, виявленні можливостей впливу уроків хореографії як предмета освітньої галузі «Мистецтво» на гармонійний розвиток і виховання школярів. Стаття присвячена одній з актуальних проблем підготовки школярів до занять із хореографрічного мистецтва розвитку культури самовираження. Основна увага зосереджується на теоретико-методичних засадах розвитку особистості школяра в хореографрічному мистецтві. У фрормуванні естетичної і художньої культури особистості хореограсрічне мистецтво розглядається як найважливіший аспект естетичного виховання, у якому поєднуються світи краси руху, звуків, світлових фрарб, костюмів, тобто світ чарівного мистецтва, що впливає на естетичну сореру світосприйняття дитини. Висвітлюються структурні компоненти, критерії, показники (організаційно-аксіологічний, комунікативний, креативний) та рівні ссрормованості досліджуваного явища. На основі аналізу психолого-педагогічної літератури обірунтовується методика формувального експерименту. В умовах сучасної мистецькоі освіти хореограсрія як навчальний предмет має бути доступною для вивчення будь-якій дитині незалежно від ї природного обдаруванння і віку як додаткова можливість ї фрізичного, естетичного, емоційного, художнього розвитку. Саме організаційно-педагогічні умови проведення хореографрічних занять у закладі загальної середньої освіти визначають специфріку форм, методів, зміст і логіку побудови уроку з хореограсрії. На шляху вибору педагогічних умов постає суперечність між: неповною визначеністю конкретних вимог у нормативних документах, що стосуються проведення занять хореографрії в закладі загальної середньоі освіти, та тими можливостями впливу на розвиток дитини, що здійснюється заняттями хореографрією. Зазначено також організаційно-педагогічні умови проведення занять хореографрії в закладі загальноі середньої освіти, їхній вплив на розвиток особистості учнів в умовах закладу загальної середньої освіти.

Ключові слова: творча діяльність, культура, хореографрія, танцювальне мистецтво, особистість школяра.
The purpose of the article is to determine and scientific substantiation of the organizational and pedagogical conditions for conducting choreographic classes in the institution of general secondary education, revealing the possibilities of influence of choreography lessons as the subject of educational branch "art", harmonious development and upbringing of schoolchildren. The article is devoted to one of the actual problems of training pupils to classes on choreographic art - development of culture of expression. The main focus focuses on the the oretical and methodical principles of development of the pupil's personality in choreographic art. In shaping the aesthetic and artistic culture of personality choreographic Art is considered as the most important aspect of aesthetic education in which combines the world of beauty movements, sounds, light colors, costumes, ie the world of magical art that influences. On the aesthetic sphere of the perception of the child. Highlights structural components, criteria, indicators (organizational-axiological, communicative, creative) and levels of formation. On the basis of the analysis of psychological and pedagogical literature, the technique of forming experiment is substantiated. In the context of contemporary art education, choreography as a subject of study should be accessible to any child regardless of their natural endowment and age as an additional opportunity for their physical, aesthetic, emotional, artistic development. The very organ of the choreography is the brains of the choreographers to borrow in the deposit of the serenity of the specialty of the forms, the method of the method, the serf' and the log to prompt the lesson from the choreographer. On the path of choosing pedagogical conditions there is a contradiction between: incomplete definition of specific requirements in the normative documents concerning conducting of choreography classes in a general secondary education institution and those opportunities for influencing the development of a child engaged in choreography classes. I'm going to have to take the choreography. The organizational and pedagogical conditions of conducting choreography classes in the general secondary education institution, their influence on the development of students' personality in the conditions of the general secondary education institution are also noted.

Key words: creative history, culture, choreography, dance-fist, specialty of schoolboy.

Харківської державної академії культури

Постановка проблеми в загальному вигляді. У Державному стандарті початкової школи (постанова Кабінету Міністрів України № 87 від 21 лютого 2018 р.) визначена окрема освітня галузь - мистецька. Метою мистецької освітньої галузі $€$ фрормування культурної та інших компетентностей, цінностей у процесі пізнання мистецтва та художньо-творчого самовираження в особистому та суспільному житті, поваги до національної та світової мистецької спадщини. Продуктивність художнього виховання дітей засобами хореографії зумовлена синтезуючим характером хореографії, яка об'єднує в собі музику, ритміку, образотворче мистецтво, театр і пластику рухів.

Аналіз останніх досліджень і публікацій. Специфріка розвивального потенціалу хореографії в різних видах танцювального мистецтва (класичний, народний, бальний та історико-побутовий танець) відображена у творчості відомих діячів: А. Ваганової, Н. Базарова, Н. Захарової, К. Заце- 
піної та ін. Розглядаючи хореографрію як засіб творчого розвитку, необхідно вказати на її синтетичні можливості. Основою хореографрії є танець фрорма організації танцювальних рухів. Серед усіх мистецтв, в єдності з якими розвивається танець, музика найбільш близька йому за узагальненістю, асоціативністю та структурними закономірностям. Але пластична образотворча мова танцю все ж більш конкретна.

Мета статті - виявлення можливостей впливу уроків хореографрії як предмета освітньої галузі «Мистецтво» на гармонійний розвиток і виховання особистості школярів.

Виклад основного матеріалу. Хореограсрію варто розглядати як засіб естетичного виховання школярів. Ії̈ специфріка визначається різнобічною дією на людину. Вирішуючи ті ж завдання естетичного й духовного розвитку і виховання дітей, що й музика, танець дає можливість фрізичного розвитку, що стає особливо важливим 3 огляду на сучасний стан здоров'я молодого покоління. Аналіз психолого-педагогічної літератури та досвід викладачів-практиків, психологів, лікарів дозволяє стверджувати, що розвиток танцювальних рухів на кожному віковому етапі відбувається по-різному. Учні молодшого шкільного віку вже порівняно добре управляють своїми рухами, їхні дії під музику більш вільні, легкі і чіткі, вони без особливої складності використовують танцювальну імпровізацію [3]. Реакція на прослуханий музичний твір являє собою творче відображення музики в дії. У цьому віці емоції, викликані музикою, створюють певну рухову активність і завдання педагога полягає в тому, щоб спрямувати їх у потрібне русло, підібравши для цього цікавий і різноманітний музично-танцювальний матеріал. Рухатися, як підказує музика, - суворий закон, якого треба неухильно дотримуватися протягом усього уроку. Рухи повинні випливати з музики, узгоджуватися з нею, відображаючи не тільки їі загальний характер, але і конкретні засоби виразності. У поєднанні образного слова, музики і руху розвивається дитяча уява, дитина точніше передає характер музичного твору, рухи стають вільними, зникає скутість, з'являється впевненість. Ще однією характеристикою танцю, значення якої настільки ж велике під час навчання дітей, як і попередніх, $€$ малюнок танцю. Усякий малюнок танцю не існує сам собою, він співвідноситься з лексикою хореографрічного твору [5].

Рухи танцю виникають і розвиваються не в абстракції, а в певному просторовому рішенні. Один рух потребує повторів, щоб затвердити себе, інший сприймається відразу і повторення не потребує. Підбір рухів у танці повинен строго відповідати поставленому завданню, тому використання нескінченно великої кількості різноманітних елементів в одному танці не завжди визначає його успіх [2, с. 3]. Танець часто ділиться на сольний і масовий. Щоби малюнок танцю дітей був чітким і виконувався ними без особливої складності, необхідно багаторазове виконання того самого руху - вправи. Коли ми намагаємося зрозуміти і пояснити, чому різні учні, поставлені у приблизно однакову ситуацію, досягають різних успіхів, ми звертаємося до поняття «здібності». I перша справа вчителя намагатися, щоб перед дитиною завжди стояле саме творче завдання». Здібності виявляються у відповідній конкретній діяльності. Особливо важливо, щоб участь у створенні танцю, його виконанні та сприйнятті була учню до снаги. Основою змісту початкового навчання є включення учнів (під керівництвом педагога) у провідні види хореографрічної діяльності. Важливі на першому етапі музично-виконавська й імпровізаційна діяльність. У молодшому шкільному віці, коли в дитини ще не блокована потреба у спілкуванні з танцем, музикою, вона із цікавістю сприймає музично-хореографрічну інфрормацію. Тому важливо залучати дітей до основ хореографрічної діяльності. Вони осягають темпо-ритмічний малюнок рухів, складну структуру образів і пластики [1, с. 13]. Особливу роль у творчому розвитку дітей засобами хореографрії відіграє участь у виконавчій, імпровізаційній і творчій діяльності. Діти відчувають потребу у вільному танці, для них це одна 3 найбільш доступних фрорм самовираження. Такого роду діяльність сприяє фрормуванню любові до танцю. Заняття ритмікою в молодшому шкільному віці набувають особливої важливості тому, що в цьому віці дитина має досить великий потенціал у розвитку спеціальних здібностей до сприйняття танцю і музики. На жаль, ці можливості із часом безповоротно втрачаються, тому необхідно як можна ефективніше використовувати їх. Творчий розвиток учнів передбачається у змісті сучасних програм уроків хореографії, але не використовується повною мірою. Мета уроків ритміки - залучення дітей до танцювального мистецтва, хореографії. «Хореографрія» - поняття дуже широке, буквально означає в перекладі із грецької «писати танець». Але із часом цим словом стали називати все, що належить до мистецтва танцю: балет, побутовий танець, професійне мистецтво, самодіяльне мистецтво [4, с. 28]. Танець $є$ найбагатшим джерелом естетичних вражень дитини, її творчих можливостей. Синкретичність танцювального мистецтва передбачає розвиток почуття ритму, вміння чути і розуміти музику, узгоджувати з нею свої рухи, водночас розвивати і тренувати м'язову силу корпусу і ніг, рухи рук, грацію і виразність. Заняття танцем на уроках ритміки формують правильну поставу, виховують основи етикету і грамотної манери поведінки в суспільстві, дають уявлення про акторську майстерність. Танець має величезне значення як засіб виховання національної само- 
свідомості. В основу навчання дітей молодшого шкільного віку необхідно покласти ігрове начало. Ідеться про те, щоб зробити гру органічним компонентом уроку. Гра на уроках ритміки не повинна бути нагородою або відпочинком після нелегкої роботи, саме фрормування певних навичок виникає на ґрунті гри, стає їі змістом і продовженням. Правильно підібрані й організовані у процесі навчання танці-ігри сприяють вмінню працювати, викликають інтерес до уроку, до роботи [5]. Специфріка навчання хореографії пов'язана 3 постійним фрізичним навантаженням. Але фрізичне навантаження само собою не має для учнів виховного значення. Воно обов'язково повинно бути сумісним із творчістю, з розумовою працею й емоційним вираженням. Завдання педагога - виховувати в дітях прагнення до творчого самовираження, до грамотного опанування емоцій, розуміння прекрасного. Перед викладачем стоїть складне завдання дати учням початкову хореографрічну підготовку. Одне із завдань навчально-тренувальної роботи правильна постановка корпусу, рук, ніг і голови, розвиток і зміцнення суглобово-зв'язкового апарату, розвиток сили і спритності, вироблення еластичності м'язів, опанування танцювальної техніки [6, с. 34]. За правильного заучування всіх цих рухів можна досягти результатів, але це не означає, що всі рухи потрібно заучити відразу. Визначаючи послідовність рухів, варто керуватися основними дидактичними правилами: від простого до складного, від легкого до важкого, від відомого до невідомого. Починати урок потрібно з невеликої амплітуди рухів, що вимагає помірної роботи окремих груп м'язів. Це рухи головою, плечима, пружинки, неглибокі присідання, носочки, руху рук тощо. Потім із постійним зростанням амплітуди і темпу - нахили, повороти, підйоми і махи ніг та ін. У кінці розминки включаються рухи, що викликають одноразове навантаження на всі групи м'язів - це стрибки, обертання і комбінації різних елементів. Систематичні заняття пропорційно розвивають фрігуру, сприяють усуненню низки фрізичних недоліків: лордозу, кіфозу, сколіозу, опуклості грудної клітини. Крім цього, розвивається координація, еластичність зв'язок, укріплюються м'язи [3]. Під час роботи з учнями молодшого шкільного віку необхідно знати вікові особливості, без яких неможливо правильно визначити зміст і напрям навчання. Для молодших школярів характерний слабкий розвиток м'язів, що зумолює швидке втомленння від фрізичних навантажень. Із-за слабкості м'язів спини вони не здатні довго утримувати корпус в підтягнутому стані. Педагог повинен звернути увагу на зміцнення і розвиток м'язів, фрормування стійких навичок правильної постави.

Слабкість дихальних м'язів, недостатньо розвинена серцево-судинна система - усі ці особливості вимагають від педагога дуже обережного збільшення фрізичних навантажень і чергування швидкого темпу з помірковані і повільним. У дітей недостатньо розвинений аналізаторний апарат: зорова, слухова, м'язова і вестибулярна чутливість. Недосконале сприйняття: діти не вміють довго слухати музику, неточно сприймають руху, погано орієнтуються у просторі. Розвиток органів почуттів, сенсорних умінь і вдосконалення сприйняття має стати першочерговим завданням навчання хореографії. У процесі роботи з дітьми необхідно пояснювати значення кожного руху, спосіб його виконання. Учень повинен знати, що виконання тих чи інших рухів не просто «примха» викладача, а цілеспрямоване виконання завдань навчально-тренувальної роботи. Потрібно пояснювати їм, що в мистецтві танцю немає «довершеності», що кожний танцювальний рух, фррагмент повинен відпрацьовуватися і вдосконалюватися до нескінченності. Але технічна досконалість танцю не повинна стати самоціллю, а процес розучування танцю не можна перетворювати на механічне повторення танцювальних рухів. Варто пам'ятати, що оволодіння тим чи іншим навиком повинно мати художньо-творчий характер. Тоді, займаючись хореографрією, учень не просто вивчить певну кількість рухів і танців, але на кожному уроці буде пізнавати своєрідну, виразну мову хореографічного мистецтва, отримає уявлення про танці, де тісно переплітаються музика і пластика [4]. Навчаючи мистецтва танцю, необхідно водночас вести і музичне виховання: вчити розуміти і слухати музику, органічно поєднувати в єдине ціле рух і музику. Зазвичай усі елементи ритмічних вправ з'єднуються в невеликі танцювальноритмічні етюди. Учням це дуже подобається, особливо якщо додати елементи гри та змагання. Творчий розвиток учнів на уроках ритміки спостерігається у процесі виконання рухів під музику. Одні, високо підстрибуючи, намагаються «зловити метелика», інші тихо «крадуться по траві». Робота учнів на уроках ритміки заповнена різними видами діяльності. Учні слухають музику, виконують рухи під музику або ритм. Їм доводиться втілювати свої фантазії в реальний образ танцю, імітувати рухи тварин або створювати образ, характер у танці. Усе це від уроку до уроку втілюється в рух від простого до складного. Немає межі дитячої франтазії. у швидкій, рухомій мелодії вони бачать і звірят, і оцінки, і людей, що біжать на роботу, і дитячий сміх тощо [1, с. 94]. Тривале вивчення, опрацювання невеликої кількості матеріалу (рухів) дає можливість якісного його засвоєння, що надалі буде міцним фрундаментом знань. Різноманітність поєднань танцювальних рухів створює враження новизни і розвиває творчу фантазію дітей. Організація занять відбувається здебільшого у фрормі гри (нестандартні уроки). Ідеться не про застосування гри як засобу розрядки на уроці, а про те, щоб 
увесь урок був пронизаний ігровим началом. Дисциплінованість, працьовитість і терпіння - ті риси характеру, які необхідні не тільки в хореографрічному класі, але і в побуті. Ці якості роками виховуються педагогами-хореографрами і визначають успіх у багатьох справах [6, с. 54]. Почуття відповідальності, так необхідне в житті, рухає дітей, що займаються хореографрією, уперед. Не можна підвести того, хто поруч стоїть у танці, не можна спізнитися, тому що від тебе залежать інші, не можна не вивчити, не виконати, не допрацювати. Акуратність у хореографрічному виконавстві, охайність фрорми в хореограсрічному класі переноситься і на зовнішній вигляд дітей у школі. Вони виділяються не тільки своєю поставою, але і зачіскою, чистотою і елегантністю носіння звичайнісінької одягу.

До 5-6-річного віку діти здатні займатися хореографрією, оскільки сформованість структур і функцій мозку дитини близька за низкою показників до мозку дорослої людини. Сучасні дані вікової психології дозволяють стверджувати, що мозок 6-річної дитини готовий до засвоєння доступної інорормації у процесі систематичного навчання. Проте варто мати на увазі, що в індивідуальному розвитку дітей того самого віку спостерігаються відхилення від середніх показників темпу дозрівання мозку і всього організму - випередження або відставання. До 6-7 років діти засвоюють поняття статі (до протилежної статі ставляться терпимо, доброзичливо), починають свідомо регулювати свою поведінку. Для них характерна стійкість, безпосередність, життєрадісність, веселий настрій. Вони здатні відчувати насолоду і переживання від сприйняття прекрасного. Виявляється потреба в зовнішніх враженнях, слуханні музики, у відвідуванні концертів, театрів, після чого діти часто зображують побачене. Важливе місце в цьому віці посідає гра - це психологічна потреба осмислення нових знань через ігри. 3 огляду на всі анатомофрізіологічні властивості дітей даного віку потрібно будувати заняття хореографрічного колективу.

7-11 років (1-3 класи) - у цьому віці відбуваються якісні та структурні зміни головного мозку (він збільшується). Відбуваються зміни і в перебігу основних нервових процесів - збудження і гальмування. Виявляються самостійність (бажання робити все самому, діти вимагають довіри від дорослих), стриманість (уміння підкоряти свої бажання загальним вимогам), наполегливість і впертість (бажання досягти результатів, навіть якщо не розуміють цілі або не мають коштів для їх досягнення). Слабкі сторони у фізіології дітей цього віку - швидке виснаження запасу енергії в нервових тканинах, тому час занять спочатку може бути обмежено і поступово має збільшуватися від 25-30 хвилин до 60, а потім і до 90 хвилин. Кістково-м'язовий апарат дітей цього віку відрізняється великою гнучкістю (значна кількість хрящових тканин і підвищена еластичність клітин). Розвиток дрібних м'язів іде повільно, тому швидкі й дрібні рухи, що вимагають точності виконання, представляють для дітей велику складність.

11-14 років (4-8 клас) - у цей період відбуваються швидкі кількісні зміни і якісні перебудови в організмі. Дитина швидко зростає (5-6, а то й 10 см на рік). 3 інтенсивним зростанням скелета і м'язів відбувається перебудова моторного апарату, яка може виражатися в порушеннях координації рухів (кажуть, що став таким незграбним). Розвиток нервової та серцево-судинної систем не завжди встигає за інтенсивним зростанням, що може в разі великого фізичного навантаження приводити до непритомності і запаморочення. Підвищується збудливість нервової системи під впливом посиленого функцціонування залоз внутрішньої секреції. Для цього віку заняття можуть проводитися тричі на тиждень, тривалістю до 1,5 години. Відбувається вивчення більш складних рухів, комбінацій, здійснюються більш об'ємні постановочні роботи.

15-17 років (9-11 класи) - у фізіологічному відношенні це період інтенсивного розвитку мускулатури, продовження розвиткумозку. Юнакитадівчата готові до фрізичного і розумового навантаження. Заняття 3 хореографії повинні будуватися з повним навантаженням. Педагог може найбільш здатним довіряти проведення занять у молодших класах.

Висновки. Для успішної роботи вчительхореограф повинен розбиратися в особливостях кожного віку. Уміло, відповідно до вікових особливостей розподіляти фрізичне навантаження. А під час формування репертуару і складання плану виховної роботи просто неможливо обійтися без урахування психологічних особливостей кожного вікового періоду. Отже, заняття хореографрії сприяють розвитку пізнавального, фрізичного, художньо-естетичного потенціалу особистості, формуванню творчої активності, уяви, мови у процесі навчання уроків ритміки. 


\section{БІБЛІОГРАФІЧНИЙ СПИСОК:}

1. Вертохина А., Самакаева М. Педагогические условия активизации профессионального самоопределения учащихся детской хореографической школы : монографрия. ФГБОУ ВПО «Уральский государственный педагогический университет». Екатеринбург, 2013. 174 с.

2. Гончаренко Ю. Моніторинг процесу викладання хореографрії у системі загальноосвітніх закладів України. Вища школа. 2011. № 4. С. 33-37.

3. Гройсман А. Методологические принципы хореографического образования. Психолого-педагогические аспекты обучения студентов театральных вузов : сборник оррагментов диссертационных исследований. Москва : Имприт, 1996. Вып. 3. С. 4-8.

4. Державний стандарт початкової освіти : постанова КМУ від 21 лютого 2018 р. № 87 . URL: https://www.kmu.gov.ua/ua/npas/pro-zatverdzhennyaderzhavnogo-standartu-pochatkovoyi-osviti.

5. Борсук Н., Мосякова І., Окушко Т. Спортивна сучасна хореограсрія : комплексна навчальна програма з позашкільної освіти. Київ, 2011. 64 с.

6. Шевчук А. Дитяча хореографрія : навчальнометодичний посібник. 3-тє вид., зі змін. та доповн. Тернопіль : Мандрівець, 2016. 288 с. 